\title{
AS UNIDADES DE PAISAGEM COMO UMA CATEGORIA DE ANÁLISE GEOGRÁFICA: O EXEMPLO DO MUNICÍPIO DE SÃO VICENTE-SP
}

\section{The landscape units as a category of geographical analysis: the example of the municipality of São Vicente-SP}

\author{
Raul Reis Amorim \\ Doutorando em Geografia, Departamento de Geografia, Instituto de Geociências, \\ Universidade Estadual de Campinas (UNICAMP). \\ raul_reis_amorim@ige.unicamp.br \\ Regina Célia de Oliveira \\ Professora Doutora, Departamento de Geografia, Instituto de Geociências, \\ Universidade Estadual de Campinas (UNICAMP). \\ reginacoliveira@ige.unicamp.br
}

Artigo recebido para publicação em 04/03/08 e aceito para publicação em 07/08/08

RESUMO: O município de São Vicente objeto de estudo desta pesquisa, incluiu-se na Baixada Santista no domínio Geomorfológico da Província Costeira no Estado de São Paulo, caracteriza-se pela ocorrência de paisagens diversas sob domínio das zonas de Serranias e Planície Costeira. Apresenta um intenso uso urbano que se estabelece sob áreas de risco vulneráveis a eventos relacionados a movimentos de massa e inundações, fatos que se agravam em razão do crescente processo de ocupação. Tendo em vista o exposto, o objetivo principal desta pesquisa foi a identificação e caracterização dos agentes e processos físico-ambientais, atuantes na área costeira no Município de São Vicente, como subsídio para a efetivação da proposta de definição de unidades da paisagem que representem os diversos níveis de fragilidades ambientais acentuadas pelo modelo de uso em que se consolida a organização do espaço na área do município. Com o propósito de alcançar tal objetivo, foi realizada a caracterização fisiográfica e o levantamento de dados de campo que subsidiou a análise dos parâmetros geomórficos, climáticos e hidrodinâmicos.

Palavras chave: Unidades de paisagem; Geomorfologia; planejamento ambiental.

ABSTRACT: The municipality of São Vicente, object of study of this research, was included in Baixada Santista in the Geomorphologic Domain of the Coastal Province in the state of São Paulo, is characterized by the occurrence of several landscapes under the domain of zones of Range and Coastal Plains. It presents an intense urban use which is established under risk areas vulnerable to events related to mass movements and floods, facts which are aggravated due to the rising occupation process. Having in sight what was exposed, the main objective of this research was identifying and characterizing the physical and environmental agents and processes, which act on the coastal area linked to the municipality of São Vicente, as a subsidy to the actualization of the proposal of defining units of the landscape which represent the many different levels of environmental fragilities accentuated by the model of use in which the organization of the space in the area of the municipality is consolidated. Intending to achieve such 
objective, it was made the physiographic characterizing, the field data raising which subsided the analysis of the geomorphic, climatic, hydrodynamic parameters.

Key-works: Landscape units; geomorphology; environmental planning.

\section{INTRODUÇÃO}

As Unidades de Paisagens se individualizam pelo relevo, clima, cobertura vegetal, solos ou até mesmo pelo arranjo estrutural e o tipo de litologia ou exclusivamente por um desses elementos (ROSS, 1992). As Unidades de Paisagem apresentam fronteiras de complexa delimitação (já que têm um espectro taxonômico variado), que ocupam um determinado espaço e certo período de tempo, cuja existência é condicionada pelo funcionamento de seus elementos (MONTEIRO, 2000).

A categoria de análise das Unidades de Paisagem é definida como geossistemas. Os geossistemas são definidos como fenômenos naturais (aspectos geomorfológicos, climáticos, hidrológicos e fitogeográficos) que englobam os fenômenos antrópicos (aspectos sociais e econômicos). Somados representam a paisagem modificada ou não pela sociedade. $\mathrm{O}$ estudo sobre geossistemas requer $\mathrm{o}$ reconhecimento e a análise dos componentes da natureza, sobretudo através das suas conexões. Entendidos os geossistemas, como unidades naturais integrais, pode-se distinguir suas modificações e transformações como resultantes das ações dos diferentes tipos de ocupação (GUERRA e MARÇAL, 2006).

No estudo dos geossistemas o conceito de paisagem é a principal categoria de análise. Bertrand (1971) define a paisagem como certa porção do espaço, resultante da interação dinâmica e instável de atributos físicos, biológicos e antrópicos, que, reagindo dialeticamente uns sobre os outros, fazem dela um conjunto único e indissociável. Christofoletti (1998) atribui à paisagem a concepção de conceitochave da Geografia que possibilita a compreensão do espaço como um sistema ambiental, físico e socioeconômico, com estruturação, funcionamento e dinâmica dos elementos físicos, biogeográficos, sociais e econômicos. As relações e distribuições espaciais desses fenômenos são compreendidas na atualidade com o estudo da complexidade inerente as organizações espaciais.

Para Bolós apud Guerra e Marçal (2006), a paisagem em sua abordagem sistêmica e complexa será sempre dinâmica e compreendida como o somatório das inter-relações entre os elementos físicos e biológicos que formam a natureza mais as intervenções da sociedade no tempo e no espaço em constante transformação.

Em uma abordagem sistêmica, as informações temáticas como vegetação, relevo, aspectos edáficos e pedológicos, substrato geológico, isoladamente, não ajudam muito na compreensão das Unidades de Paisagem. Segundo Morin (1977) e Christofoletti (1979), a configuração da paisagem depende dos elementos, relações, atributos, entradas (inputs) e saídas do sistema (output) considerando uma análise espaço-temporal.

Para Rodriguez (1994), a análise sistêmica se baseia no conceito de paisagem com um "todo sistêmico" em que se combinam a natureza, a economia, a sociedade e a cultura, em um amplo contexto de inúmeras variáveis que buscam representar a relação da natureza como um sistema e dela com o homem. Os sistemas formadores da paisagem são complexos e exigem uma multiplicidade de classificações que podem, segundo o autor, enquadrar-se perfeitamente em três princípios básicos de análise: o genético, o estrutural sistêmico e o histórico, que se fundem numa classificação complexa. 
A delimitação de Unidades de Paisagem apresenta grande complexidade, pois a interação entre os diversos atributos do sistema natural e do sistema antrópico permite a identificação dos atributos responsáveis pela dinâmica da paisagem, como também identificar as principais fragilidades ambientais de cada unidade, elemento essencial na gestão do território.

Nesse sentido, a gestão territorial como mecanismo disciplinador das ações antrópicas no meio ambiente tem reconhecidamente, nos estudos ambientais vinculados ao planejamento, o principal mecanismo de efetivação das ações no espaço territorial, sejam, por meio de diagnóstico, estudos de impactos, levantamentos físicos e territoriais, seja pela análise sócio-econômica, enfim, por mecanismos que possibilitem antever quadros futuros de organização territorial.

Dessa forma, a gestão territorial pode constituir-se ainda, ferramenta que venha garantir a equidade da distribuição territorial como prerrogativas para uma melhor qualidade de vida da sociedade.

As análises ambientais, alicerçadas em estudos setoriais ou integrando atributos físicos, econômicos e sociais de dado espaço, permite assinalar, em escalas locais ou mesmo regionais, categorias específicas de identificação e avaliação de impactos ambientais, avaliação de recursos naturais, reconhecimento de áreas de riscos geoambientais, avaliação da vulnerabilidade da área à ocorrência de eventos naturais que possam resultar em quadros de impactos catastróficos.

O município de São Vicente situa-se na região da Baixada Santista, porção central do Estado de São Paulo. A dinâmica entre os componentes naturais nesta área é bastante complexa, já que os fluxos naturais entre o ambiente serrano e o domínio das planícies são bastante intensos, ou seja, no município de São Vicente, ação continental e a ação marinha exercem grande influência na dinâmica da paisagem.
Afonso (2006) afirma que na zona costeira, as características de transição entre o oceano e o continente configuram um sistema natural ao mesmo tempo complexo e frágil, já que os rios, mar, praias e matas interagem, criando condições especiais.

Ainda segundo a autora, em estuários, lagunas, manguezais e praias, a interação oceanocontinente é mensurável a tal ponto que torna praticamente impossível a delimitação precisa do que se convencionou chamar de linha de costa.

$\mathrm{Na}$ Baixada Santista, região onde se situa o município de São Vicente, a serrania acompanha a costa, formando um grande anfiteatro, que possibilitou a formação de uma planície sedimentar. A disposição do modelado influencia diretamente aspectos ligados à dinâmica climática, à cobertura vegetal, aos processos erosivos e deposicionais, aos processos pedogenéticos e ao escoamento flúviopluvial.

Tendo em vista o exposto, o objetivo principal desta pesquisa foi a identificação e caracterização dos agentes e processos físico-ambientais, atuantes na área costeira no Município de São Vicente, como subsídio para a efetivação da proposta de definição de unidades da paisagem que representem os diversos níveis de fragilidades ambientais acentuadas pelo modelo de uso em que se consolida a organização do espaço na área do município.

\section{MATERIAL E MÉTODO}

\section{1. Área de Estudo}

A cidade de São Vicente está situada a $24^{\circ} 00^{\prime}$ S e $46^{\circ} 30^{\prime} \mathrm{W}$, no centro do litoral paulista, com uma distância de aproximadamente $71 \mathrm{~km}$ da capital e com altitude em torno de $10 \mathrm{~m}$ na área urbana, atingindo cotas altimétricas acima dos $1000 \mathrm{~m}$ na área do município que abrange o Parque Estadual da Serra do Mar (Figura 01). Ao integrar a Região Metropolitana da Baixada Santista, limita-se com os seguintes municípios: ao extremo oeste com os municípios de Itanhaém e Mongaguá, ao noroeste com 
As unidades de paisagem como uma categoria de análise geográfica: o exemplo do município de São Vicente-SP Raul Reis Amorim, Regina Célia de Oliveira

São Paulo, ao norte com São Bernardo do Campo e

Oceano Atlântico e ao sul-sudeste com Praia Grande. Cubatão ao nordeste-leste com Santos, ao sul com o

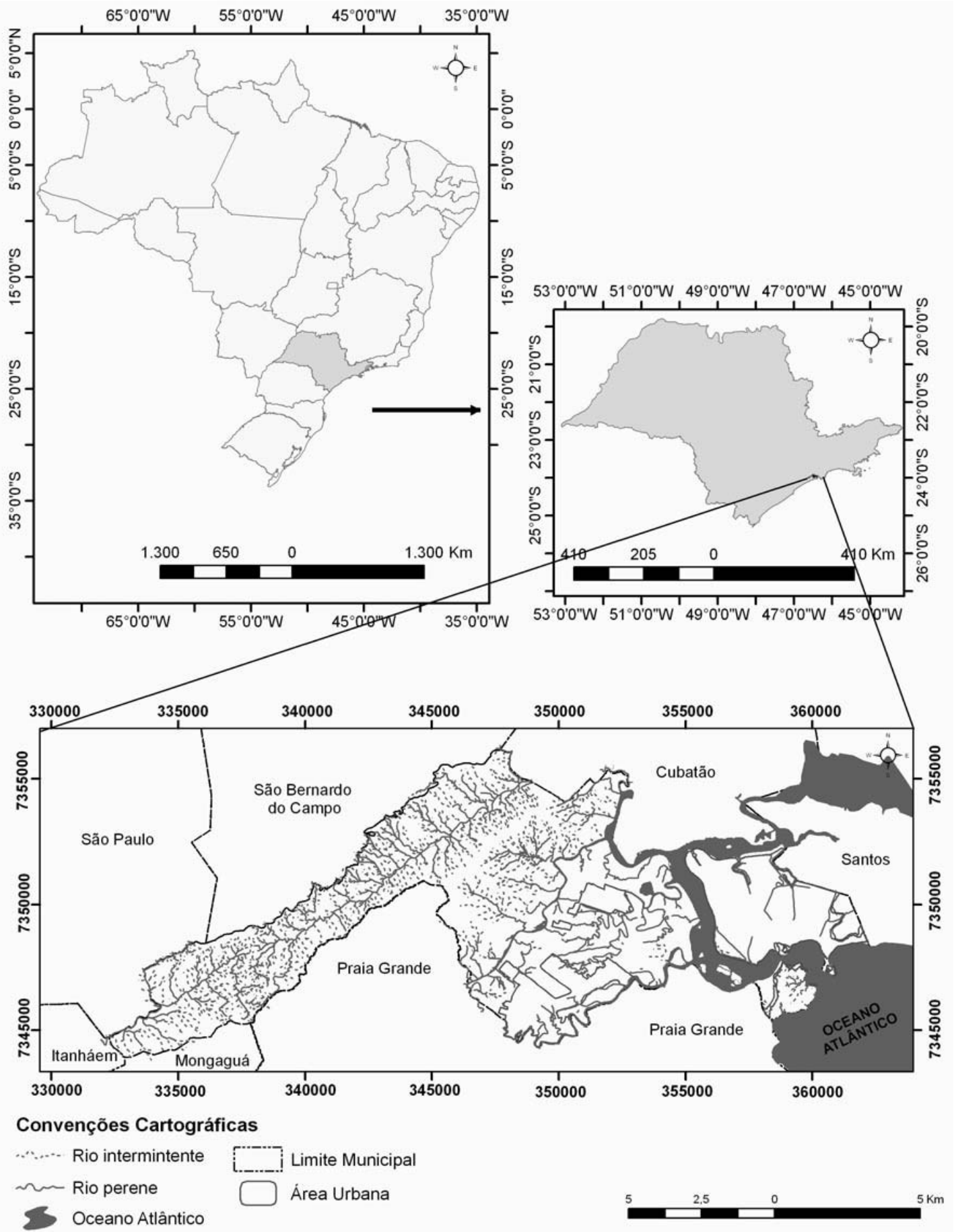

Figura 01: Localização da área de estudo.

Organização: Raul Reis Amorim.

Fonte: IBGE (2006).

Sociedade \& Natureza, Uberlândia, 20 (2): 177-198, DEZ. 2008 
2.2. Pressupostos Teóricos na Análise da Paisagem: a proposta de Rodriguez, Silva e Cavalcanti (2002).

A proposta idealizada proposta por Rodriguez, Silva e Cavalcanti (2002) fundamenta-se numa análise integrada dos componentes antrópicos e naturais a partir de uma caracterização socioeconômica e geoecológica.

Rodriguez, Silva e Cavalcanti (2002) propõem idéias, conceitos e métodos de estudo para a análise da paisagem, abrangendo os enfoques estrutural, evolutivo-dinâmico, antropogênico, integrativo da estabilidade e sustentabilidade e o funcional da paisagem.

O enfoque adotado na realização deste trabalho é o enfoque funcional na análise da paisagem. Tal enfoque segundo Rodriguez, Silva e Cavalcanti (2002) tem por finalidade esclarecer como a paisagem é estruturada, quais são as relações funcionais de seus elementos, por que está estruturada de determinada maneira (relações genéticas ou casuais) e para que esteja estruturada de certa forma (quais as funções naturais e sociais).

Este enfoque sustenta-se na necessidade de esclarecer os elementos substanciais dos subsistemas, que refletem o sistema das inter-relações externa das paisagens, que dominam sua essência e sua vida. Devido a isto, as diversas unidades das paisagens tornam-se independentes do fundo físico-geográfico comum.

Para este enfoque, a gênese da paisagem ocorre no processo de formação do geocomplexo e da determinação das relações genéticas entre seus elementos estruturais, ou seja, a forma ou modo de aparecimento da paisagem é condicionado por um determinado tipo de processo e de fatores.

A gênese paisagística é um processo que ocorre nos limites da fronteira superior da paisagem na atmosfera até o limite inferior da camada de alteração do intemperismo. Nestes limites muda a estrutura da paisagem, o regime de seu funcionamento e ocorrem os processos evolutivos. Entre os elementos estruturais dos geocomplexos, nestes limites realizase o intercambio de energia e substâncias ativas.

A ação conjunta dos fatores, componentes e processos no tempo é uma condição necessária para o efeito na formação e funcionamento da paisagem, ou seja, a gênese da paisagem propriamente dita como fenômeno. Os mencionados fatores (componentes), ao interatuar de forma permanente, formam uma unidade natural (ou seja, o fenômeno paisagísitico) que se controla pelas funções de cada um dos fatores em uma determinada medida de suas magnitudes.

O funcionamento concebe como uma das principais propriedades do complexo geográfico como geossistema que determina sua integridade e sua existência independente. É um processo geral, inerente a cada geocomplexo em qualquer período de sua existência.

Define-se como funcionamento da paisagem a seqüência estável de processos que atuam permanentemente e que consistem na transmissão de energia, substâncias e informação, garantindo a conservação de um estado da paisagem, característico para um tempo dado (ou seja, um determinado regime de funcionamento) (DIAKONOV, 1988).

$\mathrm{O}$ funcionamento da paisagem constitui um processo mediante o qual se cumprem funções, ações e determinado trabalho. É um processo de intercambio de substancias e energia que ocorre na interação dos componentes na própria paisagem com o exterior.

A função geoecológica do geossistema podese definir como objetivo que cumpre o sistema em garantir a estrutura e funcionamento, tanto do próprio geossistema, como do sistema superior ao que pertence.

Podem-se definir de maneira qualitativa, as funções geoecológicas, agrupadas em três grandes classes:

- Áreas Emissoras: são aquelas que garantem o fluxo de matéria e energia para o restante 
da área, sendo, portanto, os níveis mais elevados do terreno;

- Áreas Transmissoras: são aquelas em que ocorrem os fluxos de matéria e energia das áreas mais elevadas para as áreas mais baixas, sendo um exemplo as encostas;

- Áreas de Acumulação: são locais onde ocorre a coleta da matéria e energia provenientes das áreas mais elevadas e, a partir daí, são novamente transmitidas de forma concentrada ou seletivamente através dos canais fluviais.

Estes, segundo Rodriguez (1994), se insere no contexto de paisagens dinâmicas recentes ou em estado evolutivo. São exemplos destes ambientes, os fundos de vale e as planícies.

Tal enfoque também propõe estudos referentes à dinâmica funcional e os processos geoecológicos degradantes. Nesta perspectiva de análise, verifica-se que o conjunto dos processos que garantem o funcionamento dos geossistemas é aquele que se define como dinâmica funcional. Cada paisagem tem sua própria dinâmica funcional, que é sustentada por mecanismo e balanços de fluxos de energia, matéria e informação específicos e por uma cadeia de relações reversíveis (homeoestáticas) que asseguram a integridade e coerência do sistema (DIAKONOV, 1988).

As alterações no funcionamento e nos mecanismos das relações de auto-regulação conduzem a um processo de degradação que dá lugar a desequilíbrios na dinâmica funcional, dando como resultado uma dinâmica funcional degradante.

A degradação geoecológica define-se como a perda de atributos e propriedades sistêmicas que garantem o cumprimento das funções geoecológicas e a atividade dos mecanismos de auto-regulação. Nesta direção, a degradação tem um papel antagônico á atividade dos processos geoecológicos degradantes, que são aqueles vinculados ao funcionamento, pois conduzem á alteração dos mecanismos de autoregulação, da circulação de fluxos de energia, matéria e informação e, por conseguinte, á perda dos potenciais naturais e da capacidade produtora dos sistemas.

Os processos geoecológicos degradantes são considerados problemas ambientais. Por problema ambiental subentende-se a combinação dos diferentes objetos da racionalidade ambiental, manifestam-se os processos que desarticulam a estrutura e funcionamento dos geossistemas naturais, tendo como conseqüência dificultar o cumprimento das funções socioeconômicas e as deficiências gerais de sustentabilidade em grupos sociais.

Entre os processos geoecológicos naturais, podem-se distinguir os seguintes: erosão, deflação, perda da biodiversidade, degradação das pastagens, degradação do solo (perda do horizonte húmico, compactação), salinização, redução do nível de água subterrânea, laterização, inundações, etc.

Entre os processos geoecológicos de interação (formados pela influência decisiva da ação antrópica) podem-se distinguir os seguintes: contaminação (do solo, atmosférica e da água), alteração dos recursos hídricos etc.

Em dependência da alteração dos mecanismos de formação e regulação sistêmica das paisagens e do grau e amplitude dos processos degradantes e do nível de degradação, pode-se determinar o estado ambiental dos geossistemas. Por estado ambiental, considera-se a situação geoecológica da paisagem dada, determinada pelo tipo e grau de impacto e a capacidade de reação e absorção dos geossistemas. Pode-se representar no Mapa de Estado Ambiental as seguintes classes do estado ambiental dos geossistemas nas classes definidas no Quadro 01 (RODRIGUEZ e MARTINEZ, 1998 e GLAZOVSKIY, 1998). 
Quadro 01 - Seqüência do processo de degradação dos Geossistemas.

\begin{tabular}{|c|c|c|c|c|c|c|c|}
\hline $\begin{array}{c}\text { CLIMA } \\
\text { Processo } \\
\text { Climabiogenético }\end{array}$ & $\begin{array}{l}\text { Vegetação } \\
\text { Climax }\end{array}$ & $\rightarrow$ & $\begin{array}{l}\text { Desflorestamento } \\
\text { desaparecimento da } \\
\text { vegetação natural }\end{array}$ & $\rightarrow$ & $\begin{array}{c}\text { Cultivo incontrolado } \\
\text { Aparecimento de pragas e } \\
\text { enfermidades } \\
\text { Perda do umbral e }\end{array}$ & $\rightarrow$ & $\begin{array}{l}\text { capacidade produtiva e de } \\
\text { potencial genético }\end{array}$ \\
\hline $\begin{array}{l}\text { RELEVO } \\
\text { Morfogênese }\end{array}$ & $\begin{array}{l}\text { Morfogênese } \\
\text { Atenuada }\end{array}$ & $\rightarrow$ & $\begin{array}{l}\text { Maior escoamento } \\
\text { Menor infiltração }\end{array}$ & $\rightarrow$ & Erosão hídrica e eólica & $\rightarrow$ & $\begin{array}{c}\text { Desequilíbrio hidrológico, } \\
\text { desertificação e outros } \\
\text { processos }\end{array}$ \\
\hline $\begin{array}{c}\text { SOLO } \\
\text { Pedogênese }\end{array}$ & $\begin{array}{l}\text { Pedogênese } \\
\text { Ativa }\end{array}$ & $\rightarrow$ & $\begin{array}{l}\text { Degradação físico- } \\
\text { biológico }\end{array}$ & $\rightarrow$ & Perda de nutrientes & $\rightarrow$ & $\begin{array}{c}\text { Salinização Hidromórfica e } \\
\text { outros processos }\end{array}$ \\
\hline $\begin{array}{c}\text { PAISAGEM } \\
\text { Gênese e } \\
\text { desenvolvimento } \\
\text { da paisagem }\end{array}$ & $\begin{array}{l}\text { Paisagem em } \\
\text { estabilidade } \\
\text { homeostática }\end{array}$ & $\rightarrow$ & $\begin{array}{l}\text { Paisagem no primeiro } \\
\text { estágio de alteração das } \\
\text { relações homeoestáti- } \\
\text { cas. Ainda está quase } \\
\text { intacto o potencial } \\
\text { natural e a integridade. } \\
\text { A estabilidade natural } \\
\text { se modifica } \\
\text { antropogeneticamente }\end{array}$ & $\rightarrow$ & $\begin{array}{c}\text { Paisagem instável à crítica } \\
\text { que experimentou a perda } \\
\text { parcial da estrutura } \\
\text { espacial e funcional e da } \\
\text { integridade que dá lugar } \\
\text { à destruturação (alteração } \\
\text { das relações homeostáticas }\end{array}$ & $\rightarrow$ & $\begin{array}{l}\text { Paisagem esgotada em } \\
\text { estado muito crítico que } \\
\text { perdeu a estrutura espacial e } \\
\text { funcional. Os mecanismos } \\
\text { da estabilidade natural } \\
\text { foram eliminados. }\end{array}$ \\
\hline $\begin{array}{c}\text { SISTEMA } \\
\text { AGRÍCOLA }\end{array}$ & $\begin{array}{l}\text { Geossistema } \\
\text { Natural }\end{array}$ & $\rightarrow$ & $\begin{array}{c}\text { Sistema agrícola } \\
\text { adaptado. } \\
\text { Produtivamente alta ou } \\
\text { baixa (em dependência } \\
\text { do ingresso de energia } \\
\text { externa). }\end{array}$ & $\rightarrow$ & \begin{tabular}{|} 
Sistema agrícola de \\
compromisso. \\
Produtividade média a \\
muito alta (em dependência \\
do ingresso de energia \\
externa)
\end{tabular} & $\rightarrow$ & $\begin{array}{c}\text { Sistema agrícola } \\
\text { desintegrado. Produtividade } \\
\text { baixa ou muito baixa } \\
\text { (inclusive em dependência } \\
\text { de ingresso de energia } \\
\text { externa) }\end{array}$ \\
\hline $\begin{array}{c}\text { NÍVEL DE } \\
\text { DEGRADAÇÂO }\end{array}$ & $\begin{array}{c}\text { Sem } \\
\text { degradação }\end{array}$ & $\rightarrow$ & Pouco degradada & $\rightarrow$ & Degradada & $\rightarrow$ & Muito degradada \\
\hline
\end{tabular}

Fonte: Rodriguez, Silva e Cavalcanti (2002).

\subsection{Procedimentos Metodológicos}

Considerando as proposições apresentadas pela Metodologia adotada nessa pesquisa (RODRIGUEZ, SILVA e CAVALCANTI, 2002), foi possível, a partir da integração dos componentes naturais e elementos dos sistemas antrópico, elaborar a documentação cartográfica síntese, denominada Mapa de Unidades Geoambientais do município de São Vicente-SP (Figura 02).

Considerou-se para tal a discussão da dinâmica que rege a organização da paisagem, tendo como norteador de análise os parâmetros físicos e a dinâmica de uso do solo como prerrogativas para a discussão das fragilidades ambientais decorrentes de fenômenos naturais ou agilizados pela ação antrópica.

Cumprindo as etapas propostas por Rodriguez; Silva e Cavalcanti (2002), para a realização da fase de inventário, foram utilizadas de diversas fontes de dados coletadas in locu e em instituições de pesquisa como a Universidade Estadual de Campinas (UNICAMP), Universidade de São Paulo (USP), Universidade Estadual Paulista Júlio de Mesquita Filho, Campus Rio Claro (UNESP) e Instituto de Pesquisas Tecnológicas (IPT). Também, recorreu-se a órgão de políticas públicas, como na Prefeitura do Município de São Vicente, Defesa Civil, CETESB, DAEE e o Centro de Memória de São Vicente, conhecido como Casa de Martim Afonso. 
As unidades de paisagem como uma categoria de análise geográfica: o exemplo do município de São Vicente-SP Raul Reis Amorim, Regina Célia de Oliveira

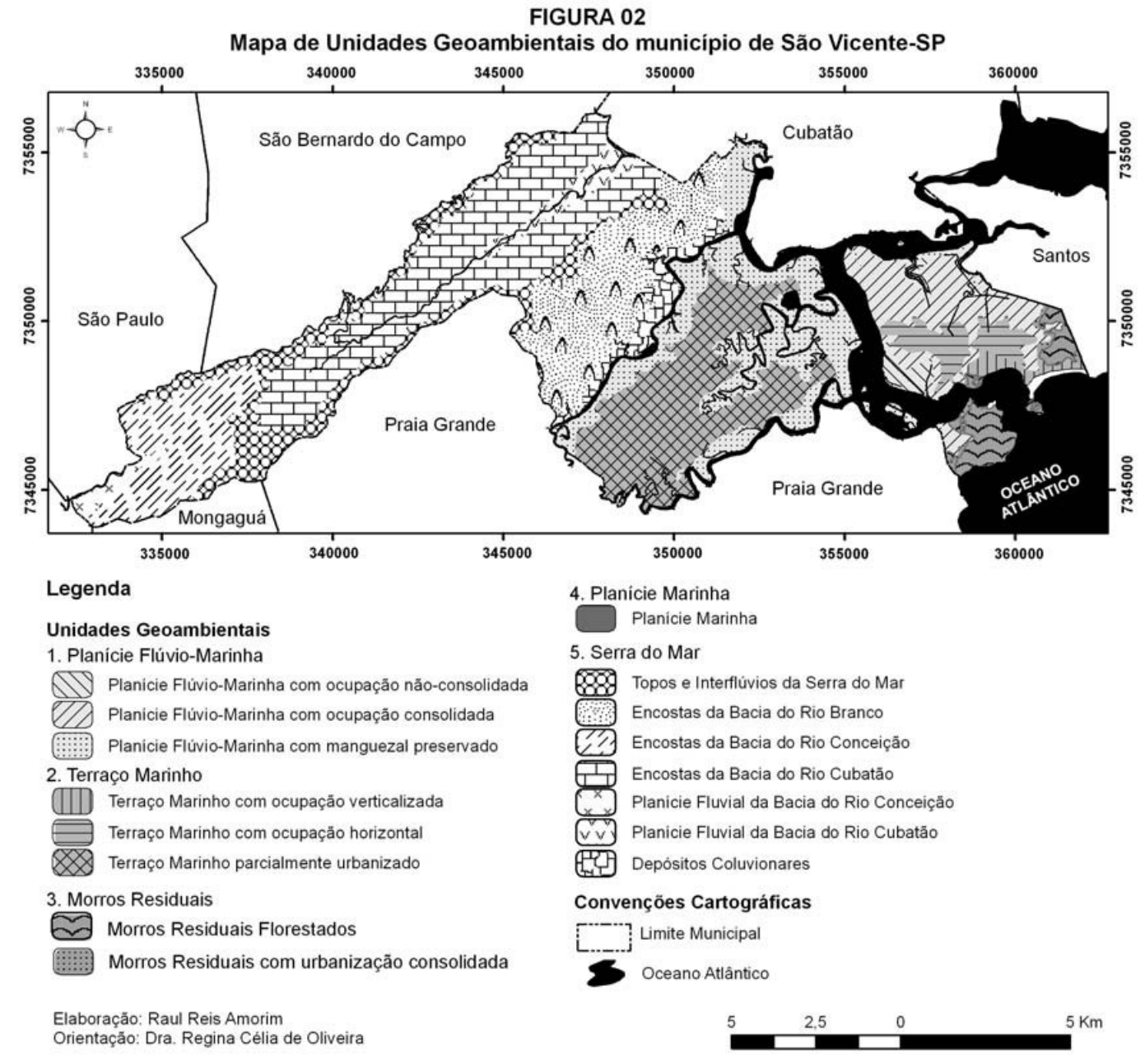

A análise da documentação cartográfica e a minuciosa correlação destas informações permitiram a particularização de áreas que apresentavam certa homogeneidade dos aspectos físicos da paisagem. Como critério básico de definição e mapeamento das Unidades Geoambientais, foi considerado em primeiro plano a Mapa de Compartimentos Geomorfológicos (Figura 03), entendendo esta como o documento que encerra para a área de pesquisa, a leitura dos principais domínios morfológicos. Tal mapa é resultante da análise visual de imagens de satélite CBERS de 2004 e da análise e interpretação de fotografias aéreas de 1962 e 1994, com escala de 1:25.000, fornecidas pelo Laboratório de Sensoriamento Remoto e Aerofotogrametria da Universidade de São Paulo (USP), e fotografias aéreas de 2002 adquiridas pelo Núcleo de Estudos

Ambientais Litorâneos (NEAL) do Laboratório de Geomorfologia do Instituto de Geociências da Universidade Estadual de Campinas (UNICAMP). A proposta deste mapa foi à delimitação dos principais compartimentos geomorfológicos da área em questão, enquadrando-os dentro de dois grandes Domínios Morfoestruturais: Domínio Morfoestrutural Planalto Atlântico (Serra do Mar) e o Domínio Morfoestrutural Planície Costeira. Verificada as diferentes feições existentes em cada Domínio Morfoestrutural, delimitaram-se também os Domínios Morfoesculturais existentes em cada Domínio Morfoestrutural: No Planalto Atlântico (Serra do Mar) delimitou-se os seguintes Domínios Morfoesculturais: (a) Topos de Interflúvios da Serra do Mar, (b) Encostas, (c) Planície Fluvial, e (d) Rampas Coluvionares, e para a Planície Costeira delimitou- 
se (a) Planície Flúvio-Marinha, (b) Terraços Marinhos e (c) Planície Marinha. O mapa foi digitalizado com o uso do software Arc GIS 9.1 e organizado na escala 1:50:000.

FIGURA 03

Mapa de Compartimentação Geomorfológica do município de São Vicente-SP

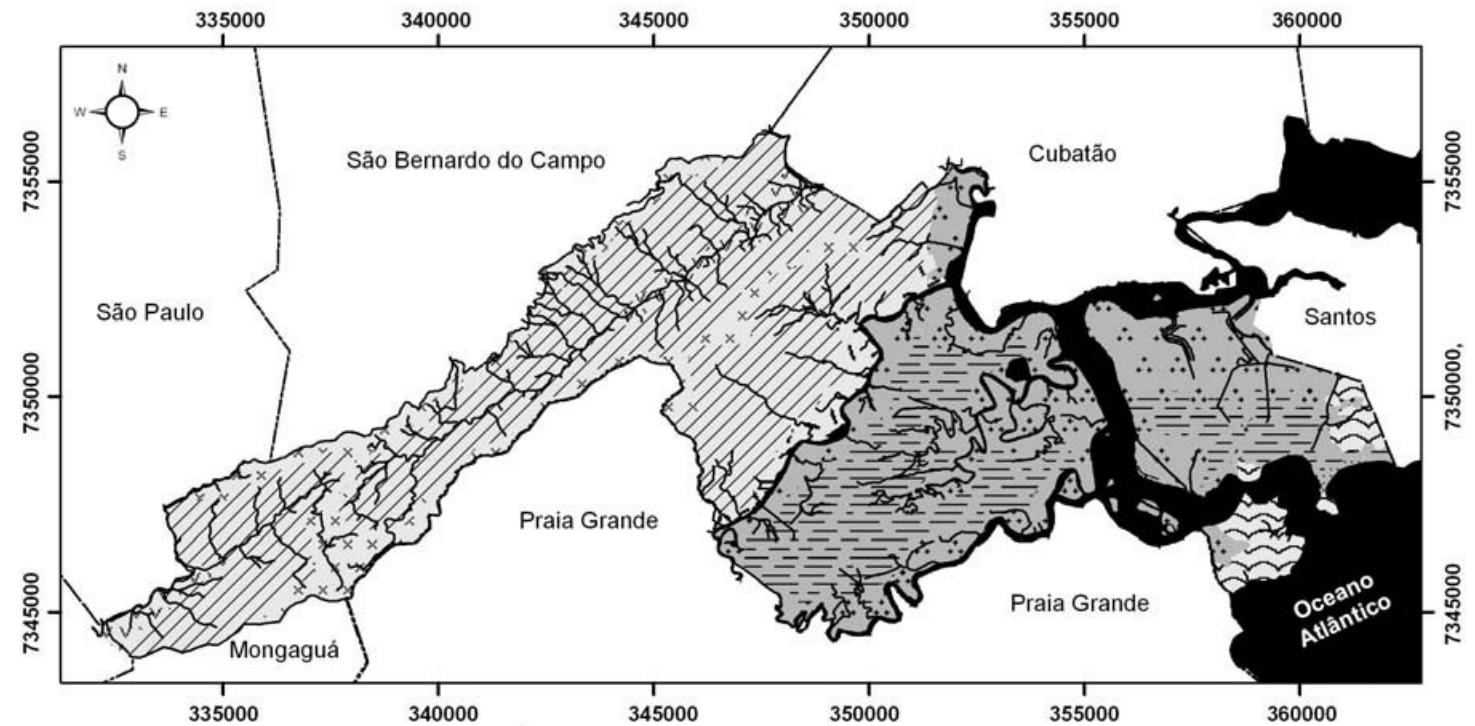

\begin{tabular}{|c|c|}
\hline \multicolumn{2}{|c|}{ Legenda } \\
\hline Compartimento Morfoestrutural & Compartimento Morfoescultural \\
\hline \multirow[t]{5}{*}{ Serra do Mar (Planalto Atlântico) } & Encostas \\
\hline & viv Fundo de Vale \\
\hline & حorro Residual \\
\hline & (1) Rampas Coluvionares \\
\hline & $\times \rightarrow$ Topos e Interflúvios \\
\hline \multirow[t]{3}{*}{ Planicie Costeira } & 9. Planicie Flúvio-Marinha \\
\hline & Planicie Marinha \\
\hline & E- Terraço Marinho \\
\hline
\end{tabular}

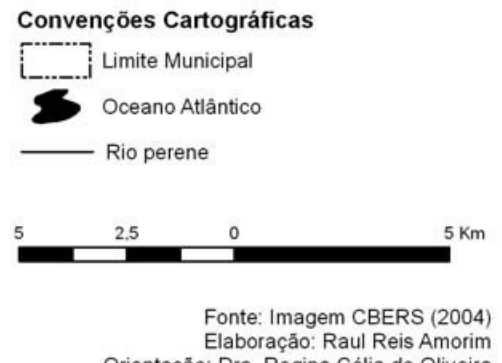

Orientaçăo: Dra. Regina Célia de Oliveira

A definição dos compartimentos geomorfológicos na delimitação das Unidades Geoambientais neste trabalho se deu considerando os apontamentos de Ross (1990, p. 12) onde "o entendimento do relevo passa, portanto pela compreensão de uma coisa maior que é a paisagem como um todo". Para o autor, não é possível abranger a gênese e a dinâmica das formas do relevo sem que se entendam os mecanismos motores de sua geração, sem que se percebam as diferentes interferências dos demais componentes em uma determinada Unidade
Geoambiental. Existe relação estreita entre tipos de formas do relevo com os solos e estes com a litologia e o tipo climático atuante.

Em segundo plano, foram consideradas os Mapas de Níveis de Ocupação (Figura 04), Estado Ambiental (Figura 05) e Uso e ocupação das Terras elaboradas para o ano de 2002 (Figura 06), sendo estes fundamentais para a análise das alterações antropogênicas na paisagem do município. 
As unidades de paisagem como uma categoria de análise geográfica: o exemplo do município de São Vicente-SP Raul Reis Amorim, Regina Célia de Oliveira

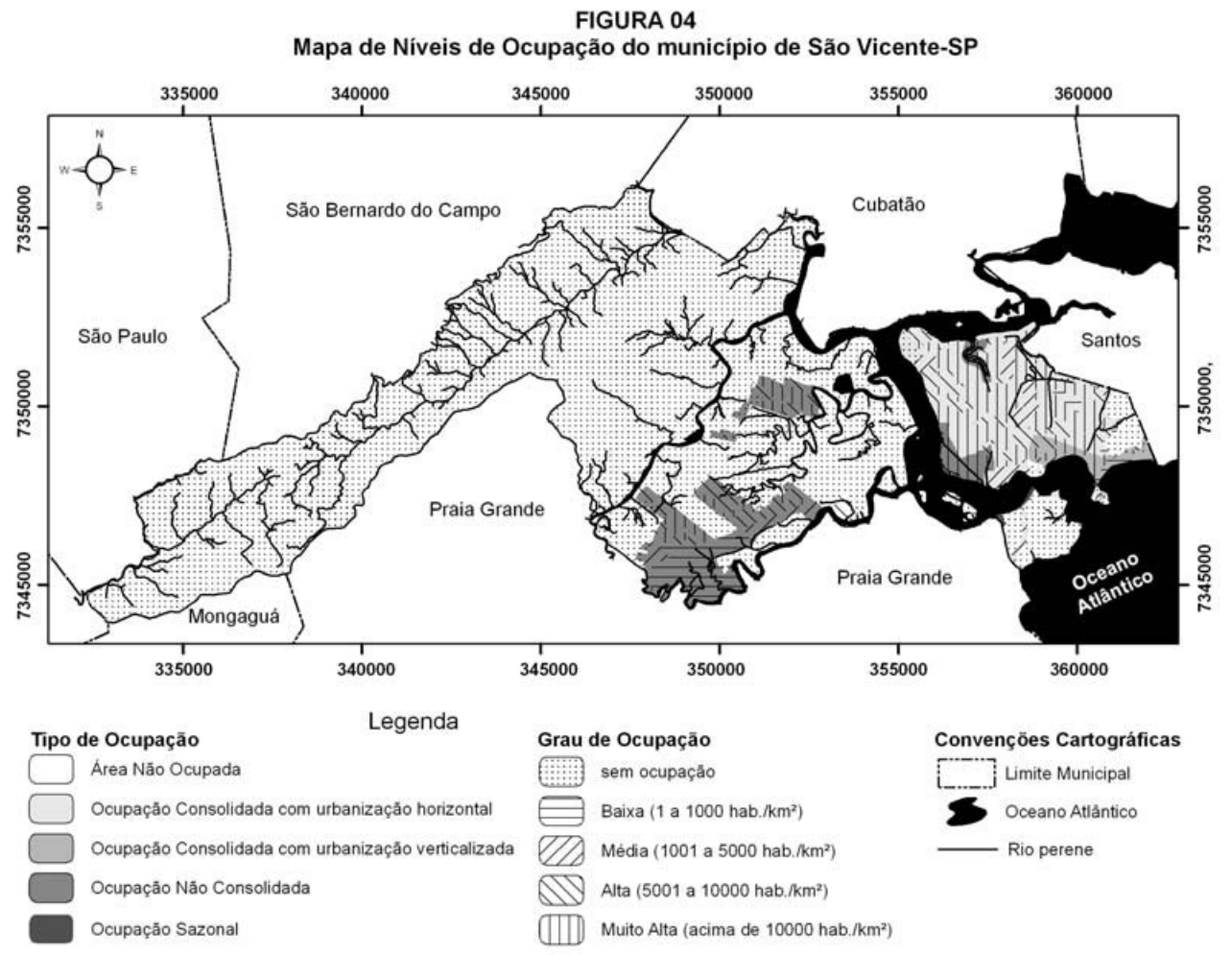

Elaboraçăo: Raul Reis Amorim
Orientaçăo: Dra. Regina Célia de Oliveira

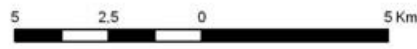

FIGURA 05

Mapa de Estado Ambiental do município de São Vicente-SP

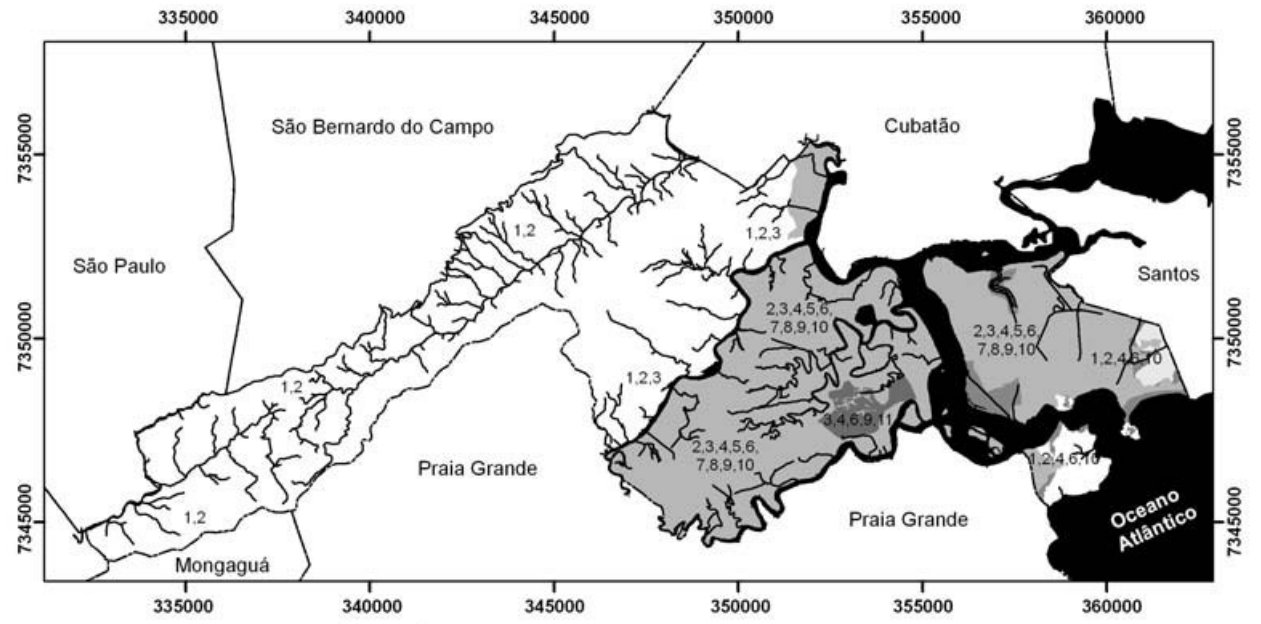

Legenda
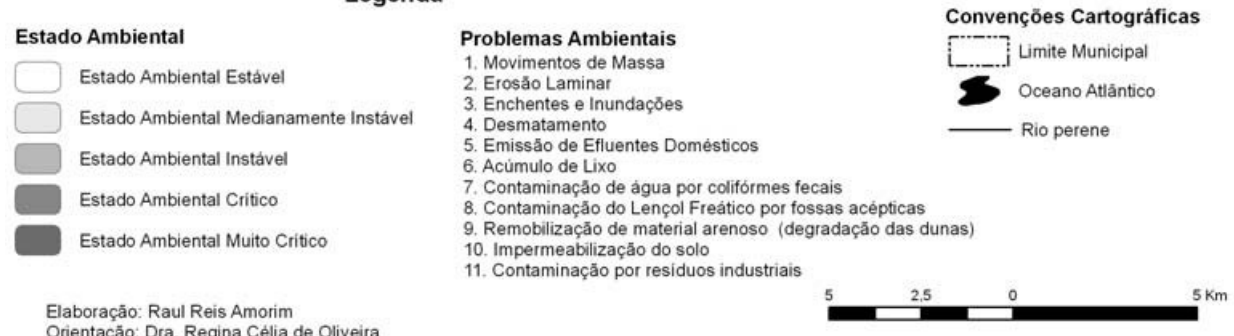


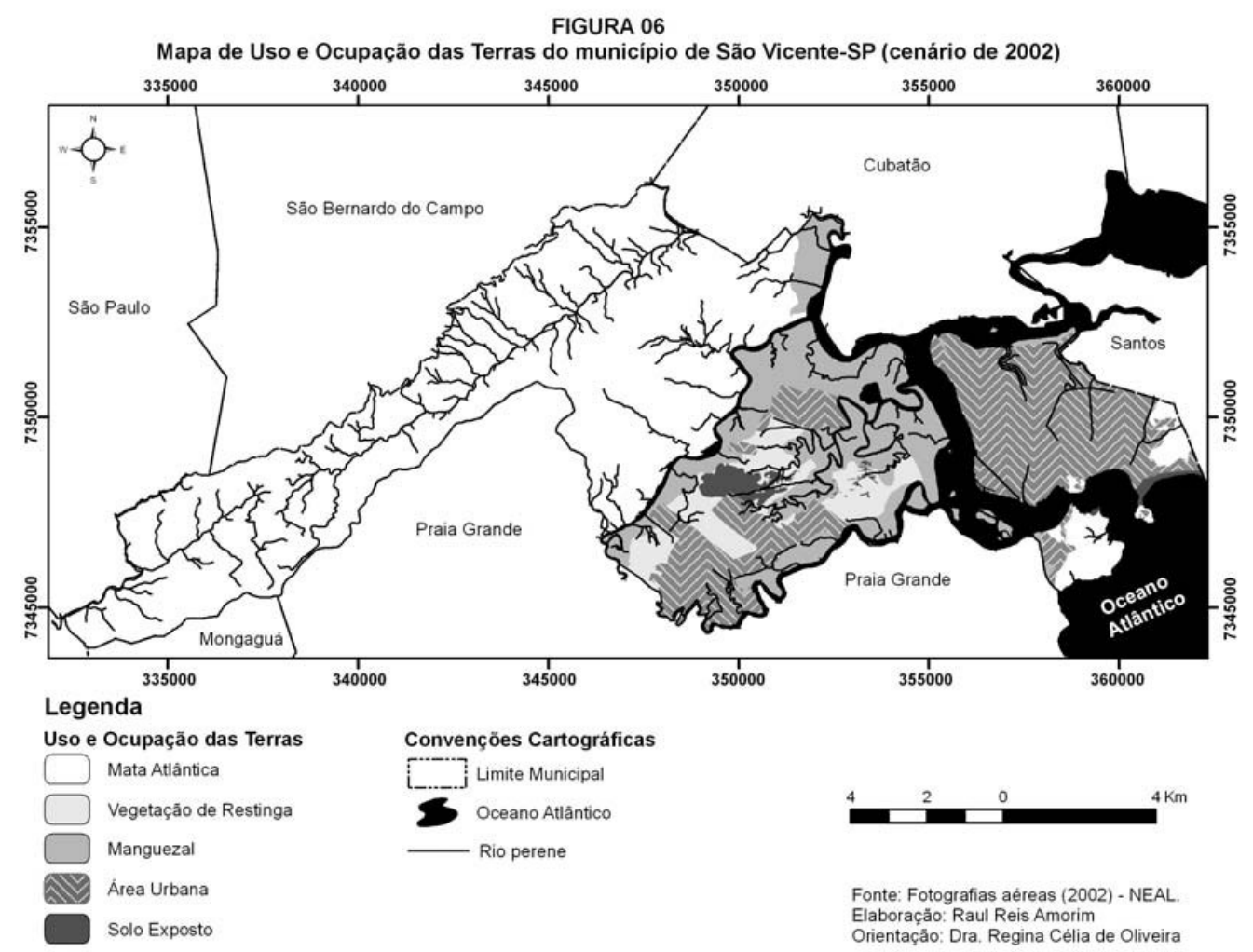

O Mapa de Níveis de Ocupação, na escala 1: 50.000 articulou informações referentes ao grau de ocupação, obtido no software Arc Gis 9.1 a partir da definição da densidade demográfica das regiões censitárias do IBGE (2000) e no tipo de ocupação, definido com base em imagens de satélites disponíveis no software Google Earth, e trabalhos de campo que percorram toda a área do município.

Também foi elaborado o Mapa de Estado Ambiental, na escala 1: 50.000 que apresenta as classes qualitativas de Estado Ambiental propostas na metodologia de Rodriguez, Silva e Cavalcanti (2002) que define o Estado Ambiental como (a) Estável, (b) Medianamente Estável (sustentável), (c) Instável (insustentável), d) Crítico e (e) Muito Crítico. Este mapa também indica os problemas ambientais para cada classe de Estado Ambiental.

O Mapa de Uso e Ocupação das Terras foi elaborado a partir da interpretação de pares estereoscópicos de fotografias aéreas na escala 1:25.000 do Núcleo de Estudos Ambientais
Litorâneos (NEAL) do Laboratório de Geomorfologia da UNICAMP.

Ao analisar esses mapas pode-se compreender a dinâmica da ocupação antrópica e a sua ação sobre os sistemas naturais, principalmente ocasionando ou acelerando impactos.

Para subsidiar as discussões, foram utilizados outros mapas que contemplam a área de estudo como o Mapa Geológico elaborado por Martin e Suguio (1978), o Mapa de Formações Superficiais (MACIEL, 2001), Pedológico adaptado de IAC (1999), Maciel (2001) e Amorim (2007), Mapa Topográfico (IGGSP, 1971), e os Mapas Hipsométrico, Clinográfico, Cobertura Vegetal Natural, Distribuição Anual de Chuvas e Geomorfológico elaborados por Amorim (2007).

O Quadro 02 mostra a regionalização do município de São Vicente a partir da delimitação de Unidades Geoambientais. 
As unidades de paisagem como uma categoria de análise geográfica: o exemplo do município de São Vicente-SP Raul Reis Amorim, Regina Célia de Oliveira

Quadro 02 - Delimitação das Unidades Geoambientais e das Sub-Unidades Geoambientais do município de São Vicente-SP.

\begin{tabular}{|c|c|c|c|c|}
\hline $\begin{array}{l}\text { Domínio } \\
\text { Morfoestrutural }\end{array}$ & $\begin{array}{l}\text { Unidade } \\
\text { Geoambiental }\end{array}$ & Sub-Unidade Geoambiental & $\begin{array}{r}\text { Área } \\
\left(\mathrm{km}^{2}\right)\end{array}$ & $\begin{array}{c}\text { Área } \\
\text { Total }(\%) \\
\end{array}$ \\
\hline \multirow[t]{7}{*}{$\begin{array}{l}\text { Planície } \\
\text { Costeira }\end{array}$} & \multirow{3}{*}{$\begin{array}{l}\text { Planície } \\
\text { Flúvio- } \\
\text { Marinha }\end{array}$} & $\begin{array}{l}\text { Planície Flúvio-Marinha com ocupação } \\
\text { consolidada }\end{array}$ & 10,51 & 7,07 \\
\hline & & $\begin{array}{l}\text { Planície Flúvio-Marinha com ocupação } \\
\text { não-consolidada }\end{array}$ & 1,85 & 1,25 \\
\hline & & $\begin{array}{l}\text { Planície Flúvio-Marinha com manguezal } \\
\text { preservado }\end{array}$ & 29,27 & 20,15 \\
\hline & \multirow{3}{*}{$\begin{array}{l}\text { Terraço } \\
\text { Marinho }\end{array}$} & Terraço Marinho com ocupação verticalizada & 1,22 & 0,82 \\
\hline & & Terraço Marinho com ocupação horizontal & 4,00 & 2,69 \\
\hline & & Terraço Marinho parcialmente urbanizado & 10,26 & 6,90 \\
\hline & $\begin{array}{l}\text { Planície } \\
\text { Marinha }\end{array}$ & Planície Marinha & 0,23 & 0,15 \\
\hline \multirow{9}{*}{$\begin{array}{l}\text { Planalto } \\
\text { Atlântico } \\
\text { (Serra do Mar) }\end{array}$} & \multirow[t]{7}{*}{ Serra do Mar } & Topos de Interflúvios da Serra do Mar & 12,55 & 8,44 \\
\hline & & Encostas da Bacia do Rio Cubatão & 25,99 & 17,48 \\
\hline & & Encostas da Bacia do Rio Conceição & 11,26 & 7,57 \\
\hline & & Encostas da Bacia do Rio Branco & 16,92 & 11,38 \\
\hline & & Planície Fluvial da Bacia do Rio Cubatão & 2,82 & 1,90 \\
\hline & & Planície Fluvial da Bacia do Rio Conceição & 1,39 & 0,93 \\
\hline & & Depósitos Coluvionares & 4,03 & 2,71 \\
\hline & \multirow{2}{*}{$\begin{array}{l}\text { Morros } \\
\text { Residuais }\end{array}$} & Morros Residuais Florestados & 0,69 & 0,46 \\
\hline & & Morros Residuais com urbanização consolidada & 3,88 & 2,61 \\
\hline
\end{tabular}

Elaboração: Raul Reis Amorim

\section{RESULTADOS E DISCUSSÕES: Análise Geoambiental do Município de São Vicente-SP}

Foram delimitadas cinco Unidades Geoambientais, sendo que estas foram divididas em SubUnidades Geoambientais.

A Unidade Geoambiental Planície FlúvioMarinha está situada no domínio morfoestrutural Planície Costeira e no domínio morfoescultural Planície Flúvio-Marinha. Esta Unidade Geoambiental é constituída por rochas oriundas de depósitos Holocenos de origem marinha e lagunar, predominando sedimentos flúvio-lagunares e de baías, e também sedimentos de mangue e de pântano (areias e argila). A cobertura superficial da área é alóctone profundo, oriundo de depósitos flúvio-marinho e lagunares, com textura argilo-siltosa. Tais sedimentos ao serem pedogenizados dão origem a Espodossolos e Gleissolos (AMORIM, 2007).

Nesta Unidade Geoambiental predominam as áreas planas e suavemente onduladas, onde escoam canais de primeira ordem, apresentando baixa energia e pequena velocidade de escoamento. A influência das marés ao longo dos canais fluviais favorece a manutenção de áreas permanentemente alagadas, onde se desenvolve a vegetação de Mangue. Apresenta amplitude altimétrica variando entre $0 \mathrm{e}$ $19 \mathrm{~m}$, com declividades inferiores a $2 \%$, definindo assim a baixa energia de relevo, com baixa dissecação (MARTIN e SUGUIO, 1978; IAC, 1999; MACIEL, 2001 e AMORIM, 2007). 
Devido às características morfológicas observam-se, diferentes tipos de Uso da Terra, Níveis de Ocupação, Estado Ambiental e Estado Geoecológico, a Unidade Geoambiental Planície Flúvio-Marinha que totaliza uma área de $42,33 \mathrm{~km}^{2} \mathrm{e}$ $28,46 \%$ da área total do município, é dividida em três Sub-Unidades Geoambientais: Planície FlúvioMarinha com ocupação consolidada, Planície FlúvioMarinha com ocupação não-consolidada e Planície Flúvio-Marinha com manguezal preservado.

A Sub-Unidade Geoambiental Planície Flúvio-Marinha com ocupação consolida representa $24,82 \%$ da área da Unidade Geoambiental Planície Flúvio-Marinha. Esta Sub-Unidade situa-se na porção insular do município de São Vicente, abrangendo uma área de $29,27 \mathrm{~km}^{2}$ e um percentual de $7,07 \%$ da área total do município.

Nesta Sub-Unidade Geoambiental a ocupação é consolidada com urbanização horizontal, que atende a população satisfatoriamente com infra-estrutura básica, como ruas pavimentadas, ligação de rede de água, coleta de esgoto e iluminação pública. A área apresenta grau de ocupação variado. Nas áreas próximas ao Jóquei-Clube, o grau de ocupação é de baixo, pois apresenta de 0 a $1.000 \mathrm{hab} . / \mathrm{km}^{2}$. No geral, predominam os graus, alto (entre $5.001 \mathrm{e} 10.000 \mathrm{hab} . /$ $\mathrm{km}^{2}$ ) e muito alto (acima de $10.0001 \mathrm{hab} . / \mathrm{km}^{2}$ ).

O Estado Geoecológico da área é definido como alterado em toda a sua extensão. Este é resultado do Estado Ambiental Instável (insustentável), em decorrência da intensa interferência antrópica que vem provocando impactos ambientais associados à urbanização consolidada da área. Dentre os problemas identificados destaca-se a impermeabilização do solo e a contaminação do lençol freático por fossas acepticas.

A Outra Sub-Unidade Geoambiental delimitada é Planície Flúvio-Marinha com ocupação não-consolidada, que representa 4,37\% da área da Unidade Geoambiental Planície FlúvioMarinha. Esta Sub-Unidade também se situa na porção insular do município de São Vicente, abrangendo uma área de $1,85 \mathrm{~km}^{2}$ e um percentual de $1,25 \%$ da área total do município.

Esta Sub-Unidade teve sua ocupação de forma expontânea, ou seja, a área foi loteada desconsiderando em muito um nível de planejamento criterioso. Desta forma, a ocupação expontânea, do tipo invasão levou a formação de grandes favelas que apresentam grandes deficiências de infra-estrutura básica.

Desde o final da década de 1990 o programa de habitação do Estado de São Paulo, vem realizando a construção de Conjuntos Habitacionais nas proximidades da favela do México 70, visando à remoção da população que ocupa as margens do manguezal em construções de palafitas.

O grande contingente populacional na área a compreende o grau de ocupação dessas Sub-Unidades como alto (entre 5.001 e $10.000 \mathrm{hab} . / \mathrm{km}^{2}$ ) e muito alto (acima de $10.0001 \mathrm{hab} . / \mathrm{km}^{2}$ ). Tal pressão demográfica faz com que nessas áreas predominem o Estado Geoecológico alterado, em decorrência das edificações, e também apresenta um Estado Ambiental Muito Crítico, pois o atual tipo de uso leva a perda parcial da estrutura espacial e funcional com eliminação paulatina das funções ecológicas. $\mathrm{O}$ impacto humano nesta área excedeu a capacidade de suporte dos geossistemas.

Tal ocupação sem a devida infra-estrutura causa um número significativo de problemas ambientais de forte intensidade, como as epidemias decorrentes da emissão de efluentes e do acúmulo de lixo. Estas Sub-Unidades Geoambientais necessitam da aplicação de medidas de mitigação urgentes e imediatas para recuperar o potencial natural.

E por fim, a Sub-Unidade Geoambiental Planície Flúvio-Marinha com manguezal preservado representa $70,81 \%$ da área da Unidade Geoambiental Planície Flúvio-Marinha. Esta SubUnidade situa-se na porção continental do município de São Vicente, abrangendo uma área de $29,27 \mathrm{~km}^{2} \mathrm{e}$ um percentual de $20,15 \%$ da área total do município. 
Esta Sub-Unidade apresenta área predominantemente não ocupada. Na área identificouse com análise de fotografias aéreas a presença ocupação pontual (casebres construídos no meio do manguezal) que não são atendidos por nenhum serviço de infra-estrutura básica.

O Estado Ambiental é definido como Pouco Degradado, pois a área apresenta apenas alguns poucos pontos de desmatamento com manchas de solo exposto. O Estado Geoecológico da área é caracterizado predominantemente como compensado, pois predomina a preservação da cobertura vegetal natural. Pontualmente, nesta Sub-Unidade, verificase um Estado Geoecológico Medianamente Estável nas áreas ocupadas por casebres e/ou desmatadas.

Em âmbito geral, as variáveis morfométricas da Unidade Geoambiental Planície Flúvio-Marinha a caracteriza como uma área acumuladora de matéria e energia. Na sua totalidade apresenta elevada Fragilidade Ambiental, principalmente em conseqüência da baixíssima declividade (inferior a $2 \%$ ), elevado volume pluviométrico e interferência constante das marés, o que deixa a área susceptível a enchentes e inundações.

A Unidade Geoambiental Terraço Marinho situada sobre o compartimento dos Terraços Marinhos é formada por depósitos de origem Pleistoceno Marinho (Formação Cananéia) e por depósitos Holocenos de origem marinha e lagunar, onde as areias marinhas foram retrabalhadas na superfície (SUGUIO e MARTIN, 1978). A cobertura superficial da área é alóctone profundo, oriundo de depósitos marinhos recentes, com textura arenosa (MACIEL, 2001). A ação dos processos pedogenéticos na área leva a gênese dos Espodossolos e Neossolos Quartzarênicos. Esta unidade se situa no domínio morfoestrutural Planície Costeira e no domínio morfoescultural Terraços Marinhos (AMORIM, 2007).

A área coberta apresenta como cobertura vegetal natural a Vegetação de Restinga, em que predominam as áreas planas e suavemente onduladas, drenadas por canais de primeira ordem, que, periodicamente recebe influência direta das marés, apresentam baixa energia e pequena velocidade de escoamento (AMORIM, 2007). Essa Unidade Geoambiental é dividida em três Sub-Unidades Geoambientais em virtude dos seguintes critérios: localização, diferentes Níveis de Ocupação, Uso da Terra e Estado Ambiental.

A Sub-Unidade Geoambiental Terraço Marinho com ocupação verticalizada situa-se na área insular, abrigando os bairros mais próximos da orla (bairros Gonzaguinha e Itararé). Essa SubUnidade Geoambiental tem área de $1,22 \mathrm{~km}^{2}$ que representa $0,82 \%$ da área total do município. Essa Sub-Unidade Geoambiental é totalmente urbanizada e seu processo de ocupação é antigo e remete ao núcleo inicial de povoamento. A área apresenta ocupação consolidada, apresentando variações quanto a seu grau de ocupação. A presença de áreas em que predomine um grau médio de ocupação (1.001 a 5.000 hab. $/ \mathrm{km}^{2}$ ) se dá devido o elevado número de imóveis destinados a segunda residência. Nas áreas onde predomina residência da população local verifica-se que o grau de ocupação varia entre alto (entre 5.001 e $10.000 \mathrm{hab} . / \mathrm{km}^{2}$ ) e muito alto (acima de 10.0001 hab. $\left./ \mathrm{km}^{2}\right)$. Esta Sub-Unidade é atendida satisfatoriamente por infra-estrutura básica.

A outra Sub-Unidade Geoambiental situada na porção insular do município é o Terraço Marinho com ocupação horizontal. Esta Sub-Unidade abriga os bairros centrais como o Bairro Beira Mar, Bitaru, Centro, Vila Valença, Vila Melo, Catipõa e Parque São Vicente. Apresenta área de $4 \mathrm{~km}^{2}$ que representa $2,69 \%$ da área total do município.

Esta Sub-Unidade é atendida satisfatoriamente por infra-estrutura básica, pois também apresenta ocupação consolidada, com variações quanto a seu grau de ocupação, como na Sub-Unidade Geoambiental Terraço Marinho com ocupação verticalizada. Podem-se encontrar porções do território com um grau médio de ocupação (1.001 a $5.000 \mathrm{hab} . / \mathrm{km}^{2}$ ) e predomínio do grau alto (entre 5.001 e 10.000 hab. $/ \mathrm{km}^{2}$ ) e muito alto (acima de $10.0001 \mathrm{hab} . / \mathrm{km}^{2}$ ) de ocupação. 
Em ambas Sub-Unidades Geoambientais são cortadas por rede de drenagem que devido à implantação dos sistemas de engenharia, foram canalizados. Outra característica da área é o grande adensamento populacional e a grande infra-estrutura instalada para atender ao turismo, principal atividade econômica do município e quase que totalmente desenvolvida nessas Sub-Unidades Geoambientais.

O Estado Ambiental da Unidade é classificado em Instável (insustentável), conseqüência da interferência antrópica secular. Os principais problemas ambientais encontrados são a impermeabilização do solo, a contaminação do lençol freático por fossas acépticas, e a poluição sonora e visual.

A Sub-Unidade Geoambiental Terraço Marinho parcialmente urbanizado tem $10,26 \mathrm{~km}^{2}$, o que corresponde a $6,9 \%$ da área municipal, situa-se na área continental e abrange parte dos bairros Nova São Vicente, Parque das Bandeiras, Jardim Rio Branco, Parque Continental, Boa Vista, Humaitá e Quaternário. Essa Unidade Geoambiental tem parte de seu território ocupado por bairros de formação recente que vem sofrendo ocupação desordenada ao longo das últimas três décadas. O grau de ocupação que varia de alto (entre 5.001 e $10.000 \mathrm{hab} . / \mathrm{km}^{2}$ ) a muito alto (acima de $10.0001 \mathrm{hab} . / \mathrm{km}^{2}$ ), acarreta problemas infra-estruturais. Nesta Sub-Unidade apresentam áreas que não são ocupadas, desta forma estando preservados fragmentos da Vegetação de Restinga, que são intercaladas com alguns pontos desmatados com solo exposto devido à extração mineral de areia.

O Estado Ambiental dessa Sub-Unidade Geoambiental é definido como Instável (insustentável), nas áreas onde se verifica uma intensa interferência antrópica, tanto decorrentes da implantação dos equipamentos urbanos, como também referente da ocupação desordenada, feita sem nenhum auxílio técnico do poder público. Os principais problemas ambientais encontrados na área são: a impermeabilização, contaminação do lençol freático por fossas acepticas, a emissão de efluentes em canais e a céu aberto, o acúmulo de lixo, a remobilização de material nos campos de dunas decorrentes do desmatamento. Nas áreas onde ocorre a contaminação da área por dejetos químicoindustriais o define-se como Estado Ambiental Muito Crítico.

Maciel (2001) relata que durante a década de 1970, a empresa francesa Rhonê-Poluente (RhodiaBrasil) utilizou setores da porção continental do município de São Vicente para depositar resíduos industriais sólidos constituídos por organocloratos, substância que, novos estudos realizados, alojam-se no organismo, preferencialmente no tecido adiposo.

O depósito localizado no Bairro Quaternário caracteriza-se por ser um dos mais graves, devido à intensa urbanização ao seu entorno. Segundo a autora, em meados da década de 1980, ao descobrir os pontos de depósitos dos resíduos organoclorados, a CETESB exigiu que a Rhodia removesse o material contaminado. Após a sua retirada, restou no local uma cava de aproximadamente 10 metros de extensão e 2 metros de profundidade. A partir de 1997, a cava vem sendo isolada, com a finalidade de impedir a ocupação desses setores e a contaminação das áreas adjacentes (MACIEL, 2001).

Os fatores naturais, como a baixa declividade (inferior a $2 \%$ ), a topografia plana com baixa amplitude altimétrica caracterizam essa área como acumuladora de matéria e energia. Outro fator a ser considerado é o elevado volume pluviométrico e a interferência constante das marés associados à intensa ocupação relacionada com o alto índice de impermeabilização, deixa a área com elevada probabilidade a enchente e inundações o que elevam a Fragilidade Ambiental dessa Unidade Geoambiental.

A Unidade Geoambiental Planície Marinha limita-se com o Oceano Atlântico e o Terraço Marinho. Apresenta área de $230 \mathrm{~m}^{2}$, correspondendo a $0,15 \%$ da área total do município. É constituída por depósitos de origem Pleistoceno Marinho. Tal material é remobilizado continuamente pela ação da 
dissipação das ondas marinhas (SUGUIO e MARTIM, 1978).

Segundo Amorim (2007), a Planície Marinha é parcialmente coberta por uma vegetação rasteira, típica do extrato herbáceo da Vegetação de Restinga. Geomorfologicamente, a Planície Marinha situa-se no domínio morfoestrutural Planície Costeira, apresentando como fisionomia característica a presença de praias dissipativas com baixíssima declividade (inferior a 2\%).

$\mathrm{O}$ autor ressalta que a área é intensamente explorada para atividades turísticas. Nas praias ocorre o estabelecimento de cabanas, bares, restaurantes que atendem a demanda dos banhistas e esportistas que freqüentam as praias do município. Sendo assim, podemos afirmar que a Unidade Geoambiental tem uma ocupação sazonal, pois o número de pessoas que ocupam este espaço varia de acordo com a época do ano.

Esta Unidade Geoambiental apresenta Estado Ambiental Crítico. Tal Estado Ambiental é decorrente da intensa interferência antrópica que tem gerado impactos provenientes das edificações implantadas na área que levam a impermeabilização, o despejo de esgoto e acúmulo de lixo. A Balneabilidade das praias é um parâmetro a ser utilizado para a definição do Estado Ambiental dessa Unidade Geoambiental.

As praias do município de São Vicente participaram do programa de Balneabilidade das praias, desenvolvido pela CESTESB, com o respaldo legal junto à Resolução CONAMA n . 20/86, que define critérios para a classificação das águas destinadas à recreação de contato primário.

De acordo com esta Resolução, até o ano de 2005, as praias são classificadas em quatro categorias diferenciadas: excelente, muito boa, satisfatória e imprópria, conforme a densidade de coliformes totais ou fecais resultantes de análises feitas em cinco amostragens consecutivas. As categorias denominadas de excelente, muito boa e satisfatória podem ser agrupadas numa única classificação denominada própria.
A partir de 2006 a CETESB reformulou o critério de qualificação anual das praias, com o intuito de discriminar melhor as praias, aumentando o número de categorias de 4 para 5. Essa alteração decorreu do fato de que a categoria regular abrangia uma faixa muito ampla de qualidade das praias, englobando em uma mesma qualificação praias de qualidade distintas. Por exemplo, as praias eram classificadas como Regular, quando apresentavam condições impróprias uma única vez por ano, e até praias que estiveram impróprias entre $40 \%$ e $50 \%$ do tempo. Deste modo a categoria Regular foi dividida em duas (REGULAR e RUIM) e a categoria Má foi renomeada para PÉSSIMA.

Desta forma, densidades de coliformes fecais superiores a $100 \mathrm{NMP} / 100 \mathrm{~mL}$ em duas ou mais amostras de um conjunto de cinco amostragens consecutivas, em um período igual ou superior a cinco semanas, caracterizam a impropriedade da praia para a recreação de contato primário.

A balneabilidade das praias constitui um fator indicativo das condições de saneamento básico de um determinado local. No caso específico do município de São Vicente, fica claro que essas condições refletem um sistema de infra-estrutura deficitário, que vem perdurando ao longo dos anos. A falta de ação do poder público com a aplicação de investimentos, principalmente ligados ao saneamento básico, comprometendo assim o Estado Geoecológico dessa Unidade Geoambiental.

Deixando as Unidades Geoambientais situadas no domínio morfoestrutural Planície Costeira, e analisando as Unidades Geoambientais situadas no domínio morfoestrutural Planalto Atlântico (Serra do Mar), compartimentou-se duas Unidades Geoambientais: A Unidade Geoambiental Serra do Mar e a Unidade Geoambiental Morros Residuais.

A Unidade Geoambiental Serra do Mar abrange a área do Parque Estadual da Serra do Mar, criado em 1977. Apresenta uma área de $74,96 \mathrm{~km}^{2}$, abrangendo $50,41 \%$ da área total do município. 
Constitui-se por do Pré-Cambriano que foram metamorfizadas ganhando grande resistência aos processos intempéricos. Há predomínio dos migmatitos de estrutura complexa (policíclicos) de paleossoma predominantemente gnássico (MARTIN e SUGUIO, 1978). A ação dos agentes intempéricos associados aos processos pedogenéticos dá gênese na área Cambissolos Háplicos e Neossolos Litólicos intercalados por afloramentos rochosos que estão cobertos pela Floresta Ombrófila Densa (Mata Atlântica) (IAC, 1999 e AMORIM, 2007).

Esta Unidade Geoambiental foi compartimentada em sete Sub-Unidades Geoambientais considerando-se a dinâmica dos fatores naturais, dentre eles a função Geoecológica, as condições da drenagem, os aspectos morfométricos, as formações superficiais e o domínio morfoescultural em que se situam. As Sub-Unidades Geoambientais delimitadas são: Topos de Interflúvios da Serra do Mar, Encostas da Bacia do Rio Conceição, Encostas da Bacia do Rio Cubatão, Encostas da Bacia do Rio Branco, Planície Fluvial da Bacia do Rio Conceição, Planície Fluvial da Bacia do Rio Cubatão e Depósitos Coluvionares.

A Sub-Unidade dos Topos de Interflúvios da Serra do Mar têm 12,55 km², o que corresponde a $8,44 \%$ da área municipal e $16,44 \%$ da área total da Unidade Geoambiental Serra do Mar.

Esta Sub-Unidade Geoambiental situa-se no domínio Morfoescultural dos Topos de Interflúvios da Serra do Mar, onde a ação intempérica forma uma cobertura superficial autóctone pouco profundo, oriundo de rochas cristalinas intemperizadas in situ, com textura areno-argilosa (MACIEL, 2001). Na área predominam os topos aguçados cobertos por Floresta Ombrófila Densa que dão origem as nascentes dos rios que drenam as Bacias dos Rios Conceição, Cubatão e Branco. A área situa-se nos pontos mais elevados do município, variando entre 725 a $1020 \mathrm{~m}$. Tal posição na paisagem somada ação da gravidade, faz com que nessa Sub-Unidade Geoambiental predominem os processos erosivos superficiais e escoamento superficial das águas das chuvas, o que caracteriza a área como emissora de matéria e energia (AMORIM, 2007).

Outras Sub-Unidades Geoambientais delimitadas foram as Encostas da Bacia do Rio Branco, Encostas da Bacia do Rio Conceição e Encostas da Bacia do Rio Cubatão. Estas SubUnidades apresentam características semelhantes, embora se devam considerar os desníveis altimétricos que correspondem às respectivas bacias hidrográficas.

As três Sub-Unidades são transmissoras de matéria e energia. Apresentam a cobertura superficial do tipo autóctone pouco profundo, oriundo de rochas cristalinas intemperizadas in situ, com textura arenoargilosa (MACIEL, 2007). Tal cobertura superficial ao sofrer processos pedogenéticos dá gênese a Cambissolos Háplicos e Neossolos Litólicos intercalados por afloramentos rochosos (AMORIM, 2007). Estes solos são cobertos pela Floresta Ombrófila Densa (Mata Atlântica).

A Sub-Unidade Encostas da Bacia do Rio Branco os desníveis altimétricos variam de 100 a 500 metros com declividades superiores a $30 \%$, onde predominam canais de primeira ordem. $\mathrm{Na}$ área a drenagem escoa no sentido SO-NE. Verifica-se também que há a presença de inúmeros canais temporários formados em decorrência das grandes torrentes. Esta Sub-Unidade apresenta uma área de $16,92 \mathrm{~km}^{2}$, o que corresponde a $11,38 \%$ da área total do município e $22,57 \%$ da área total da Unidade Geoambiental Serra do Mar.

A Sub-Unidade Encostas da Bacia do Rio Conceição apresenta uma área de $11,26 \mathrm{~km}^{2}$, o que corresponde a $7,57 \%$ da área total do município enquanto a Sub-Unidade Encostas da Bacia do Rio Cubatão tem área de $25,99 \mathrm{~km}^{2}$, o que equivale a $17,48 \%$ da área total do município.

A principal característica que difere a SubUnidade Geoambiental Encostas da Bacia do Rio Conceição da Sub-Unidade Geoambiental Encostas da Bacia do Rio Cubatão são as maiores amplitudes nas cotas altimétricas na primeira Sub-Unidade (varia 
de 180 a $900 \mathrm{~m})$ e o sentido da drenagem, que escoa no sentido NE-SO. Já a segunda Sub-Unidade apresenta menor amplitude altimétrica, pois suas cotas oscilam entre 120 e $600 \mathrm{~m}$ e a sua rede de drenagem escoa no sentido oposto, ou seja, no sentido SO-NE.

Outras Sub-Unidades delimitadas são a Planície Fluvial da Bacia do Rio Conceição e Planície Fluvial da Bacia do Rio Cubatão. A primeira tem área de $1,39 \mathrm{~km}^{2}$, o que corresponde a $1,39 \%$ da área total da Unidade Geoambiental Serra do Mar, enquanto a segunda apresenta área de 2,82 $\mathrm{km}^{2}$, o equivalente a $3,76 \%$ da área total da Unidade Geoambiental em estudo.

A posição na paisagem faz dessas duas SubUnidades Geoambientais áreas acumuladoras de matéria e energia, pois elas recepcionam todo o material emitido e transportado pelas Sub-Unidades Geoambientais a montante.

Uma característica importante dessas unidades é o modelado bastante dissecado e entalhado, observa-se a ocorrência de vales em "V", o que acentuam as declividades sempre superiores a $30 \%$. Nestas áreas ocorre a confluência entre os afluentes perenes e temporários com os rios principais (AMORIM, 2007).

A última Sub-Unidade Geoambiental demarcada a ser estudada é a Depósitos Coluvionares. Esta situa-se no contato entre o setor serrano (Sub-Unidade Encostas da Bacia do Rio Branco), marcado por declives acentuados, e a Unidade Geoambiental da Planície Flúvio-Marinha parcialmente preservada, com declives muito baixos. Esta Sub-Unidade representa 5,38\% da área total da Unidade Geoambiental Serra do Mar, pois apresenta uma área de $4,03 \mathrm{~km}^{2}$, o que equivale a $2,71 \% \mathrm{da}$ área total do município.

Esta Sub-Unidade Geoambiental é formada por rampas coluvionares de procedência alóctone pouco profundo, com textura areno-argilosa, Seu material é de origem clástica, de natureza diversificada, mal selecionados do ponto de vista granulométrico e mineralógico, com morfoscopia de grande irregularidade (MACIEL, 2001).

Nesta Sub-Unidade escoam canais de primeira ordem em direção a Unidade Geoambiental Planície Flúvio-Marinha. Existência de inúmeros canais temporários formados em decorrência das grandes torrentes, que predominantemente seguem o sentido W-E (AMORIM, 2007).

Assim como as Sub-Unidades Geoambientais Encostas das Bacias do Rio Branco, Conceição e Cubatão, a Sub-Unidade Geoambiental Depósitos Coluvionares é transmissora de matéria e energia, uma vez que, os fluxos gravitacionais a montante, fazem com que a matéria e a energia que são transportados por essas áreas acumulem-se nas áreas mais rebaixadas (a Planície Fluvial, a Planície FlúvioMarinha e o Terraço Marinho).

Toda a Unidade Geoambiental Serra do Mar apresenta elevada Fragilidade Ambiental Natural, pois mesmo com Estado Ambiental Estável (não alterado), pois segundo Rodriguez (1994) as características dessa Unidade Geoambiental conserva a estrutura original. Não existem problemas ambientais significativos que deteriorem a paisagem. O nível dos processos geoecológicos tem um caráter natural. A influência antropogênica é muito pequena. São núcleos de estabilidade ecológica, principalmente paisagens primárias ou paisagens naturais com limitado uso antropogênico.

Desta forma, nesta Unidade Geoambiental, verifica-se que os processos morfogenéticos predominam sobre os processos pedogenéticos. Este predomínio da morfogênese sobre a pedogênese, decorrente da elevada energia do relevo e sua intensa dissecação. Isso se dá principalmente pela elevada amplitude altimétrica com as cotas variando dos 60 a $1.020 \mathrm{~m}$, as declividades superiores a $30 \%$, a composição do modelado, caracterizado por vales encaixados e encostas bastante escarpadas, que somadas aos elevados índices pluviométricos, à ação da gravidade e à estrutura falhada e fraturada propiciam a ocorrência de movimentos de massa (AMORIM, 2007). 
Toda a área dessa Unidade Geoambiental se situa em uma Unidade de Conservação, o Parque Estadual da Serra do Mar, criado em 1997. A área não apresenta ocupação, pois a entrada e uso na área são restritos. Nos limites do Parque Estadual da Serra do Mar, no contato com Unidade Geoambiental da Planície Flúvio-Marinha parcialmente preservada, existem algumas pequenas propriedades rurais que, segundo a COMDEC, são propriedades ilegais, oriundas de invasão.

A última Unidade Geoambiental a ser analisada é a Unidade Geoambiental dos Morros Residuais. Esta apresenta formação geológica semelhante à Unidade Geoambiental da Serra do Mar, isto é, é composta por rochas formadas no PréCambriano que foram metamorfizadas ganhando grande resistência aos processos intempéricos, onde predominam os migmatitos de estrutura complexa (policíclicos) de paleossoma predominantemente gnássico (SUGUIO e MARTIN, 1978).

A cobertura superficial da área é autóctone pouco profundo, oriundo de rochas cristalinas intemperizadas in situ, com textura areno-argilosa, onde os processos pedogenéticos desenvolvem os Cambissolos Háplicos e Neossolos Litólicos intercalados por afloramentos rochosos (IAC, $1999 \mathrm{e}$ MACIEL, 2001).

Uma característica marcante dessa Unidade Geoambiental é a baixa densidade de drenagem. Não se visualizam canais fluviais estabelecidos, mas apenas canais temporários que escoam água das torrentes. Seu relevo é intensamente dissecado, apresentando elevada energia, e sendo caracterizada como morros isolados, com encostas bastante escarpadas, com predomínio de vertentes retilíneas e convexas, que apresentam altitudes de no máximo 219 m com declives superiores a 30\% (AMORIM, 2007).

Esta Sub-Unidade Geoambiental foi compartimentada em duas Sub-Unidades Geoambientais: a primeira, a Sub-Unidade Geoambiental Morros Residuais Florestados, apresenta área de $3,88 \mathrm{~km}^{2}$, o que satisfaz a 2,61\% da totalidade da área municipal e $84,97 \%$ da área total da Unidade Geoambiental Morros Residuais, e, a segunda a Sub-Unidade Geoambiental Morros Residuais com ocupação consolidada tem área de $690 \mathrm{~m}^{2}$, o que corresponde a $0,46 \%$ da área municipal e $15,03 \%$ da área total da Unidade Geoambiental em estudo.

A Sub-Unidade Geoambiental Morros Residuais Florestados é coberta pela Floresta Ombrófila Densa (Mata Atlântica). Esta Sub-Unidade Geoambiental não é ocupada por residências e estabelecimentos comerciais, e apresenta áreas em que o acesso e uso são restritos (Parque Estadual do Xixová-Japuí). O Estado Ambiental Estável, e o Estado Geoecológico da área é compensado, pois mantém a cobertura vegetal natural.

A Sub-Unidade Geoambiental Morros Residuais com ocupação consolidada é caracterizada por apresentar uma ocupação urbana classificada como consolidada, ocorrendo de forma horizontal e vertical com grau de ocupação variando de média (1.001 e $\left.5.000 \mathrm{hab} . / \mathrm{km}^{2}\right)$ e alto $(5.001 \mathrm{a}$ $\left.10.000 \mathrm{hab} . / \mathrm{km}^{2}\right)$. A área apresenta Estado Ambiental Crítico, pois a ação antrópica acelera e acentua os processos desencadeadores de Movimentos de Massa. O Estado Geoecológico desta Sub-Unidade é o mais complexo para a totalidade do município, pois seu território apresenta áreas totalmente alteradas com ocupação urbana, vários pontos de esgotamento, que coincidem com as cicatrizes de Movimentos de Massa e áreas de compensação, que são as áreas isoladas com preservação da cobertura vegetal natural.

Esta Unidade Geoambiental apresenta elevada Fragilidade Ambiental, decorrente das suas características naturais como a elevada declividade, morfoestrutura falhada e fraturada, pacote sedimentar pouco espesso e intenso volume pluviométrico. Tais características associadas à ação antrópica aumentam os riscos a processos erosivos, a Movimentos de Massa em geral como queda de blocos, deslizamentos, desabamentos e rastejamentos.

Amorim e Oliveira (2007) ao realizar um inventário das ocorrências de Movimentos de Massa 
realizado entre 1989 e 2007 no Laboratório de Riscos Ambientais do IPT, verificaram a ocorrência de 44 Movimentos de Massa, sendo que 61,37\% foram classificados como Escorregamentos Planares. Outro tipo de movimento de massa expressivo nesta Unidade Geoambiental são as Quedas de Bloco que entre 1989 e 2007 , representaram $22,73 \%$ das ocorrências.

\section{CONSIDERAÇÕES FINAIS}

Os resultados obtidos na delimitação das Unidades Geoambientais mostram que, no município de São Vicente, que tem um contingente populacional situado acima dos 303 mil habitantes, ocupam cerca $25 \%$ da área total do município. Verificou-se que as atividades rurais não apresentam expressividade no município, pois estas se restringem a pequenas propriedades rurais situadas no limite do Parque Estadual da Serra do Mar.

O sitio urbano assenta-se predominantemente na Planície Flúvio-Marinha e no Terraço Marinho. As demais áreas, cerca de $75 \%$, são ocupadas por Unidades de Conservação, como o Parque Estadual da Serra do Mar e o Parque Estadual Xixová-Japuí que tem como principal objetivo proteger a Mata Atlântica, a vegetação de mangue e os campos de dunas, que segundo a legislação Federal, Estadual e Municipal também deveriam está sobre proteção.

O estudo dos atributos naturais do município possibilitou identificar que na área predomina a morfogênese sobre pedogênese, pois no ambiente serrano o relevo é intensamente dissecado pela ação dos agentes intempéricos, enquanto na zona de planície o que predomina são os processos deposicionais, oriundos de diferentes mecanismos (deposição fluvial, eólica e marinha).

Existe uma desproporcionalidade entre as áreas onde predominam os sistemas naturais e as áreas onde predominam os sistemas antrópicos. Nas áreas onde predominam os sistemas naturais a delimitação de Unidades de Conservação objetiva a sua proteção. Nas áreas ainda não protegidas por tal mecanismo legal, como as áreas de encostas florestadas, vegetação de Restinga e vegetação de Mangue apresentam forte tendência a transformações ambientais decorrente do crescimento populacional, da expansão urbana e do uso dos recursos naturais.

Os sistemas ambientais do município de São Vicente apresentam fragilidade a processos de degradação natural, como os Movimentos de Massa nos setores de encosta e as enchentes e inundações nas áreas planas.

A fragilidade ambiental é acentuada nas áreas urbanizadas pelo grande adensamento demográfico. A ocupação concentrada e desordenada gera o esgotamento dos recursos naturais, desequilibrando os fluxos de matéria, energia e informação nas Unidades Geoambientais.

Nas Unidades Geoambientais Planície Costeira e Terraço Marinho ocupadas pela expansão urbana levam a impermeabilização do solo que impede a infiltração da água, como também ocasionou a canalização dos cursos d'água. Tais fatores correlacionados as baixas declividades, a dinâmica pluviométrica e a influência das marés ocasionam na área enchentes e inundações.

A forma como se instalam e se distribuem a infra-estrutura nestas Unidades Geoambientais ocasionam impactos como a contaminação dos níveis freáticos pelas fossas acépticas, o acúmulo de lixo, a poluição das águas, do ar e visual, prejudicando assim a qualidade de vida da população.

Nas áreas onde a ocupação não é consolidada, a presença de favelas formadas de maneira expontânea, concentra mais de 10.000 hab. $/ \mathrm{km}^{2}$ em casas de madeira (muitas delas palafitas), não atendidas por infra-estrutura básica, o que leva a constante presença de epidemias na área.

Na Unidade Geoambiental Morros Residuais, em especial a Sub-Unidade Geoambiental Morros Residuais com ocupação consolidada a fragilidade ambiental natural é acentuada pelo processo de ocupação secular da área. Mesmo apresentando 
apenas $0,46 \%$ da área total do município, a área apresenta graves problemas ambientais, decorrentes da própria morfologia natural e acentuados pela ação antrópica.

Os Movimentos de Massa são processos naturais que juntamente com os processos erosivos são responsáveis pela evolução das encostas. Os setores de encosta do município de São Vicente apresentam elevada susceptibilidade a Movimentos de Massa, destacando os Escorregamentos Translacionais com transporte de solos e detritos e a Queda de Blocos. Essa susceptibilidade está diretamente vinculada aos elevados índices pluviométricos, à acentuada declividade e estado do material (área intensamente fraturada, com cobertura detrítica superficial e material rochoso exposto).

O processo de ocupação dos setores de encosta da área urbana do município de São Vicente ocasionou a insustentabilidade quanto ao uso, gerando como conseqüência um sério comprometimento dos fluxos de matéria e energia dos sistemas ambientais. Torna-se necessário o constante acompanhamento dessas áreas, seguidos de novos estudos criteriosos que venham contribuir com a tomada de decisões e subsidiar a gestão desses espaços minimizando os impactos ambientais.

\section{REFERÊNCIAS BIBLIOGRÁFICAS}

AFONSO. C. M. A paisagem da Baixada Santista: urbanização, transformação e conservação. Edusp/ FAPESP: São Paulo, 2006.

AMORIM, R. R. Análise Geoambiental com ênfase aos setores de encosta da área urbana do município de São Vicente-SP. 2007. 194p. (Mestrado em Geografia), Universidade Estadual de Campinas, Campinas. 2007.

AMORIM, R. R.; OlIVEIRA, R. C. Análise Geoambiental dos setores de encosta da área urbana de São Vicente-SP. Sociedade e Natureza. Ano 19, n. 37. 123-138. 2007.
BERTRAND, G. Paisagem e geografia global. Esboço metodológico. São Paulo: Universidade de São Paulo, Instituto de geografia, Cadernos de Ciências da Terra, (13) p. 1-27. 1971

Cetesb. Companhia de Tecnologia de Saneamento Ambiental. Disponível em www.cetesb.sp.gov.br. Acessado em 20/10/2007.

CHRISTOFOLETTI, A. Análise de sistemas em geografia. São Paulo: Hucitec, 1979.

CHRISTOFOLETTI, A. Modelagem de sistemas ambientais. São Paulo: Edgar Blücher, 1998.

DIAKONOV, K. N. Geofísica das paisagens: método dos balances. Moscou. Editora da Universidade Estadual de Moscou. 1988, 96p. (Tradução de J. M. M. Rodriguez)

GLAZOVSKIY, N. F. et al. Map of the state of the environmental. A global overvie. Bulletim I. G. U. p. 48. v. II. 1998. P.29-34

GUERRA, A. J. T.; MARÇAL, M. S. Geomofologia ambiental. Rio de Janeiro: Bertrand Brasil, 2006.

IAC, Instituto Agronômico de Campinas. Mapas Pedológicos do Estado de São Paulo: legenda expandida. Embrapa. Campinas, 1999.

IBGE. Instituto Brasileiro de Geografia e Estatística. Base das regiões censitárias: município de São Vicente-SP. Brasília, 2006. CD-ROM.

IGG-SP. Instituto Geográfico e Geológico do Estado de São Paulo. Folha Mongaguá (SG 23-V-A-III-2). São Paulo, IGGSP, 1971. Escala 1: 50.000.

IGG-SP. Instituto Geográfico e Geológico do Estado de São Paulo. Folha Riacho Grande (SG 23-Y-CVI-4). São Paulo, IGGSP, 1971. Escala 1: 50.000.

IGG-SP. Instituto Geográfico e Geológico do Estado de São Paulo. Folha Santos (SG 23-Y-D-IV-3 e SG 23-V-B-I-I). São Paulo, IGGSP, 1971. Escala 1:50.000. 
MACIEL, G. C. Zoneamento Geoambiental do município de São Vicente (SP), utilizando o Sistema de Informação Geográfica - SIG. 2001. 150p. (Mestrado em Engenharia Ambiental) Universidade de São Paulo, São Carlos, 2001.

MONTEIRO, C. A. F. Geossistemas: a história de uma procura. São Paulo: Contexto, 2000.

MORIN, Edgard. O método: a natureza da natureza. Lisboa. Publicações Europa-América, 1977. (Coleção Biblioteca Universitária).

ROSS, J. L. S. Geomorfologia, ambiente e planejamento. São Paulo:Contexto, 1990. (Coleção Repensando a Geografia).

ROSS, J. L. S. O registro cartográfico dos fatos geomórficos e a questão da taxionomia do relevo. Revista do Departamento de Geografia da USP. São Paulo: n. 6. 1992. 17-29p.

RODRIGUEZ, J, M. M. Análise e síntese da abordagem geográfica da pesquisa para o planejamento ambiental. Revista do Departamento de Geografia da FFLCH/USP. São Paulo, v. 9. 1994.

RODRIGUEZ, J. M. M. MARTINEZ, M. C. La regionalización geoecológica como base para La deternimación Del estudo y La situación médioambiental de Cuba. La Havana: Seccíon Cubana de la U. G. I. 1998. 12p.

RODRIGUEZ, J. M. M.; SILVA, E. D.; CAVALCANTI, A. P. B. Geoecologia da paisagem: uma visão geossistêmica da análise ambiental. Fortaleza: EDUFC, 2002.

SUGUIO, K; MARTIN, L. Mapa geológico: Folha Santos. São Paulo: DAEE/USP/FAPESP. Escala 1:100.000, 1978. 